\title{
The influence of environmental heterogeneity on the morphological and genetic diversity of Circaea lutetiana (Onagraceae) in Hyrcanian forests
}

\author{
Sedigheh NIKZAT ${ }^{1}$, Somayeh GHASEMZADEH-BARAKI ${ }^{2}$, Somayeh NAGHILOO \\ ${ }^{1}$ Faculty of Life Sciences \& Biotechnology, Shahid Beheshti University, Tehran, Iran. \\ ${ }^{2}$ Young Researchers and Elite Club, North Branch, Islamic Azad University, Tehran, Iran. \\ ${ }^{3}$ Department of Biological Sciences, University of Calgary, Calgary, Alberta T2N 1N4, Canada.
}

"Correspondence: Ghasemzadeh.barki@gmail.com

${ }^{1}$ https://orcid.org/0000-0001-5946-0683, ${ }^{2}$ https://orcid.org/0000-0003-4310-7062

${ }^{3}$ https://orcid.org/0000-0003-1492-1962

\begin{abstract}
Environmental gradients are important factors that can potentially influence the genetic diversity and differentiation of populations. The present study examines the effect of environmental heterogeneity of the Hyrcanian forests on populations of Circaea lutetiana L. (Onagraceae). Using morphometrics, scanning electron microscopy (SEM) of leaf epidermis, and molecular markers, we analyzed genetic diversity and differentiation among nine populations from environmentally divergent habitats. Three different gene pools were observed. Our results indicate that the genetic structure is significantly correlated to environmental factors, but not to the geographical distance. Genetic clustering in $C$. lutetiana is affected by temperature, humidity, elevation, and average annual rainfall. Overall, our data indicate that gene flow does not contribute to explaining spatial patterns of genetic structure and the adaptation to the environment is the main factor shaping the genetic structure of the C. lutetiana populations. The populations belonging to each of the three gene pools have similarities in microclimate parameters, despite their geographical proximity, and populations from the same genetic pool can be up to $470 \mathrm{~km}$ apart. This evidence, as well as morphological and genetic similarities of the populations with greater geographical distance, suggest the possibility of cryptic speciation in this species.
\end{abstract}

Keywords. Circaea lutetiana, environmental heterogeneity, gene flow, genetic diversity, Hyrcanian forests.
Resumen. Los gradientes ambientales son factores importantes que pueden influir potencialmente en la diversidad genética y la diferenciación de las poblaciones. El presente estudio examina el efecto de la heterogeneidad ambiental de los bosques hircanos en las poblaciones de Circaea lutetiana $\mathrm{L}$. (Onagraceae). Mediante un estudio morfométrico, microscopía electrónica de barrido (SEM) de la epidermis foliar y marcadores moleculares, analizamos la diversidad genética y la diferenciación entre nueve poblaciones de hábitats ambientalmente divergentes. Se observaron tres grupos genéticos diferentes. Nuestros resultados indicaron que la estructura genética se correlacionó significativamente con los factores ambientales, pero no con la distancia geográfica. La agrupación genética en $C$. lutetiana se vio afectada por la temperatura, la humedad, la elevación y la precipitación media anual. Nuestros datos indican que el flujo de genes no contribuye a explicar los patrones espaciales de la estructura genética y que la adaptación al medio ambiente es el factor principal que da forma a la estructura genética de las poblaciones de $C$. lutetiana. Las poblaciones que pertenecen a cada uno de los tres grupos genéticos tienen similitudes en términos de parámetros de microclima, a pesar de su proximidad geográfica, y poblaciones del mismo grupo genético pueden estar separadas hasta por $470 \mathrm{~km}$. Esta evidencia, así como las similitudes morfológicas y genéticas de las poblaciones con mayor separación geográica, sugieren la posibilidad de especiación críptica en esta especie.

Palabras clave. Bosques hircanos, Circaea lutetiana, diversidad genética, flujo genético, heterogeneidad ambiental.

How to cite this article: Nikzat S., Ghasemzadeh-Baraki S., Naguiloo S. 2021. The influence of environmental heterogeneity on the morphological and genetic diversity of Circaea lutetiana (Onagraceae) in Hyrcanian forests. Anales del Jardin Botánico de Madrid 78: e110. https://oi.org/10.3989/ ajbm. 2562

Title in Spanish: La influencia de la heterogeneidad ambiental en la diversidad morfológica y genética de Circaea lutetiana (Onagraceae) en los bosques hircanos. Associate Editor: Javier Fuertes-Aguilar.

Received: 5 May 2020; accepted: 16 April 2021; published online: 30 June 2021.

\section{INTRODUCTION}

The maintenance of genetic diversity is a fundamental prerequisite for species evolution that determines the ability of natural populations to cope with multiple biotic and abiotic stress factors (Frankham \& al. 2002; Khan \& al. 2015). The genetic diversity of populations is mainly controlled by gene flow, genetic drift and natural selection (Eckert \& al. 2008). Gene flow can increase the genetic variability via introducing new genes into local populations (Hou \& Lou 2011) and is often constrained by the distance between neighboring populations and the presence of 
landscape barriers. More closely situated populations tend to be more genetically similar (Slatkin 1993; Hutchison \& Templeton 1999; Medrano \& Herrera 2008). On the other hand, landscape barriers and environmental isolation of populations can limit gene flow (Duarte \& al. 2015) and lead to low genetic diversity (Spehn \& Körner 2005).

Plant species facing high levels of environmental heterogeneity within their distribution range need to develop adaptive strategies suited to their particular habitat including a variety of morphological, phenological and molecular changes (Ahmad \& Prasad 2011; Wheeler \& al. 2015; Little \& al. 2016). Such adaptive genetic changes are often fixed within populations through natural selection resulting in genetic differentiation and diversity among populations from different environmental ranges. Temperature and moisture are among the main environmental factors that can affect genetic differentiation and diversity among populations (Still \& al. 2005).

Based on recent phylogenetic studies, the genus Circaea L. (Onagraceae) consists of eight species and six subspecies distributed in Eurasia and North America (Xie \& al. 2009). All Circaea species are tender, broad-leaved, shadeand moisture-loving herbs. The overall area of the genus closely coincides with the area of temperate mesophilic forests of the northern hemisphere (Wagner \& Hoch 2009). Three characters, indehiscent fruit, a longer floral tube, and a pubescent stem, distinguish $C$. lutetiana from other species in the genus (Boufford 2005).

Two reproduction modes including rhizome and seed production are expected for Circaea lutetiana (Stearns 1989; Verburg \& During 1998). Its life cycle shows the features of pseudo-annuals plants which survive the winter as seeds and hibernacles produced by the rhizome apices (Verburg \& al. 1996; Verburg \& During 1998). In the pseudoannuals plants, new rhizomes produced by shoot form a new ramet in the next growing season, not in the same year (Verburg \& al. 1996). Moreover, the flowering of C. lutetiana occur from June to August (van der Meijden 1990) could be through self-compatibly, flowers diurnally, outcrossing, and pollinating by syrphid flies and small bees, or sometimes autogamously (Wagner \& al. 2007).

Circaea lutetiana is a pluri-regional species distributed as a subcosmopolitan/cosmopolitan element of Hyrcanian forests of Iran, as well as, Europe, north of Africa and southwest of Asia (Akhani \& al. 2010). The Hyrcanian forests ecological region is an area of lush lowland and montane forests extending from the south of Azerbaijan to about $900 \mathrm{~km}$ to the east into the Iranian provinces of Gilan, Mazandaran and Golestan. The occurrence of Hyrcanian forests between the northern slope of the Alborz Mountain and the southern edge of the Caspian Sea results in a high habitat heterogeneity (Akhani \& al. 2010). Circa- ea lutetiana is distributed across wide range of microhabitats with remarkable heterogeneity regarding the density of the vegetation, altitude, temperature, sun exposure degree and humidity. Some studies over such environmentally heterogeneous microhabitats have suggested the influence of climatic conditions on plant genetic structure (Nevo 2001; Hamasha \& al. 2013).

For the present study, we hypothesized that the effect of climatic and altitudinal heterogeneity of the environment would have a role in shaping patterns of macro/micro-morphological and genetic diversity among populations of $\mathrm{Cir}$ caea lutetiana. Using morphometric, leaf epidermal scanning and two genetic markers, start codon targeted (SCoT) and direct amplification of minisatellite DNA (DAMD), we aim to answer the following questions: (i) Is there a significant relationship between morphological and genetic diversity of populations; (ii) how is genetic diversity distributed among and within populations of $C$. lutetiana; (iii) is genetic diversity related to geographical distance of population or to differences in climate conditions. The influence of gene flow and natural selection in shaping genetic diversity will be discussed.

\section{MATERIAL AND METHODS}

\section{Plant material and study area}

Forty-five plant accessions were collected from nine geographical populations belonging to three provinces in the north of Iran. Circaea lutetiana is a pseudo annual clonal plant (Verburg \& al. 2000). We tried to collect individuals from different clones in order to represent different genets of the population. Details of localities are provided in Table 1 and Fig. 3. Voucher specimens are deposited in the Herbarium of Shahid Beheshti University (HSBU). Fresh leaves were collected and used for DNA extraction and molecular study. The study habitats show remarkable environmental heterogeneity regarding vegetation density, altitude, temperature, humidity and annual rainfall (Table 1). According to the vegetation density, three types of habitats could be distinguished including deep dark and dense forest, low-density forest, and very low-density forest along the forest road. The study area spans between $49^{\circ} 00^{\prime}$ to $54^{\circ} 47^{\prime}$ longitude and $35^{\circ} 10^{\prime}$ to $41^{\circ} 36^{\prime}$ latitude, and at elevations from 210 to $1700 \mathrm{~m}$. The mean year temperature (AMT) ranges between $11.83-18.6{ }^{\circ} \mathrm{C}$. The mean yearly rainfall (AP) ranges between $27.12-139.09 \mathrm{~mm}$. In contrast with other populations that exhibit wet/sub-wet conditions, the Masoleh and Zirab populations grow on the edge of the river and have a lower mean year temperature $\left(11-12^{\circ} \mathrm{C}\right)$. Information about environmental factors of the study area was provided from the State Meteorological Organization of Iran. 
Table 1. Habitat and locality information of studied populations and their environmental conditions. Lon (longitude), Lat (latitude), Elev (elevation), MAT (mean annual temperature), AP (mean annual precipitation). Forest populations (Pop): HJ (Hezar-jerib), LA (Lavij), LI (Liresar), MA (Masoleh), NA (Naharkhoran), SA (Sangdeh), SH (Shastkalateh), ZI (Zirab), ZY (Zyarat). All vouchers were deposited at the HSBU herbarium.

\begin{tabular}{|c|c|c|c|c|c|c|c|c|c|}
\hline Pop & Province, locality & Voucher & Microhabitat & Lon & Lat & Elev (m) & $\operatorname{MAT}\left({ }^{\circ} \mathbf{C}\right)$ & AP & Humidity \\
\hline SA & Mazandaran, Savadkooh & Nikzat2018630 & Deep dark, dense forest & $53^{\circ} 10^{\prime}$ & $35^{\circ} 10^{\prime}$ & 1500 & 16.5 & 37.6 & Sub-wet \\
\hline NA & Golestan, Gorgan & Nikzat2018625 & Deep dark, dense forest & $54^{\circ} 47^{\prime}$ & $36^{\circ} 76^{\prime}$ & 620 & 17.5 & 2.8 & Wet \\
\hline LI & Mazandaran, Tonekabon & Nikzat2018631 & Deep dark, dense forest & $50^{\circ} 51^{\prime}$ & $41^{\circ} 36^{\prime}$ & 1100 & 17.2 & 1.9 & Wet \\
\hline ZY & $\begin{array}{l}\text { Golestan, Gorgan, Zyarat } \\
\text { village, above waterfall }\end{array}$ & Nikzat2018626 & $\begin{array}{l}\text { Very low density forest } \\
\text { (next to road) }\end{array}$ & $54^{\circ} 23^{\prime}$ & $36^{\circ} 37^{\prime}$ & 1700 & 17.5 & 2.8 & Wet \\
\hline $\mathrm{SH}$ & Golestan, Gorgan & Nikzat2018632 & $\begin{array}{l}\text { Deep dark and dense } \\
\text { forest }\end{array}$ & $54^{\circ} 21^{\prime}$ & $36^{\circ} 48^{\prime}$ & 210 & 17.5 & 2.8 & Sub-wet \\
\hline LA & $\begin{array}{l}\text { Mazandaran, Amol, } \\
\text { Chamestan, }\end{array}$ & Nikzat2018629 & $\begin{array}{l}\text { Very low density forest } \\
\text { (next to road) }\end{array}$ & $52^{\circ} 02^{\prime}$ & $36^{\circ} 22^{\prime}$ & 900 & 17.2 & 1.9 & Sub-wet \\
\hline HJ & Mazandaran, Neka & Nikzat2018628 & $\begin{array}{l}\text { Very low density forest } \\
\text { (next to road) }\end{array}$ & $53^{\circ} 32^{\prime}$ & $36^{\circ} 33^{\prime}$ & 670 & 18.6 & 1.5 & Sub-wet \\
\hline MA & Gilan, Masole & Nikzat2018634 & Low density forest & $49^{\circ} 00^{\prime}$ & $37^{\circ} 09^{\prime}$ & 800 & 11.8 & 1.3 & $\begin{array}{l}\text { High-wet } \\
\text { river edge }\end{array}$ \\
\hline ZI & Mazandaran, Savadkooh & Nikzat2018633 & Low density forest & $52^{\circ} 58^{\prime}$ & $36^{\circ} 07^{\prime}$ & 1000 & 12.4 & 1.4 & $\begin{array}{l}\text { High-wet } \\
\text { river edge }\end{array}$ \\
\hline
\end{tabular}

\section{Morphological data}

A total of 10 quantitative and 5 qualitative morphological characters were investigated. For morphological analyses, the mean of 10 individuals was used as representative of each population. The studied features included leaf-base shape, petal color, seed trichome type, leaf margin shape, stigma notch type, petal/sepal length, stamen/pistil length, petal notch/petal length, leaf/petiole length, length/width of leaf, stamen/petal length, length/width of seed, length of seed tip, and distance between teeth in the same leaf.

For the scanning electron microscopy (SEM) study, a small segment from the central part of the leaf abaxial surface was placed on aluminum stubs with double-sided cellophane tape and coated with gold. The specimens were examined with a Phillips $\times$ L20 SEM. UTHSCSA Image Tools Version 3.0 was used to measure quantitative and qualitative features including the shape of guard cells, peristomatal rim, ridge and striation patterns on the cuticular membrane, stomatal pole, length/width of stomata (L/W), stomatal rim location, outer surface ornamentation of guard cells were studied (Table 2). For the terminology of epidermal features, we follow Bartholtt \& al. (1998) and Pole (2010).

\section{DNA extraction and primer amplification (DAMD and SCoT)}

CTAB-activated charcoal was used for total genomic DNA extraction (Ghasemzadeh Baraki \& al. 2018). The quality of DNA samples was determined by the electrophoresis on $1 \%$ agarose gel. Four DAMD primers -viz., URP9F, URP2F, URP25F, URP38F- and four SCoT primers-viz., SCoT2, SCoT3, SCoT7, SCoT18- commercialized by UBC (the University of British Columbia) were used (Collard \& Mackill 2009; Kang \& al. 2002).

PCR reactions for SCoT and DAMD markers were carried out in a $25 \mu \mathrm{l}$ volume containing $10 \mathrm{mM}$ Tris- $\mathrm{HCl}$ buffer at pH 8.3, $2.5 \mathrm{mM} \mathrm{MgCl2,1} \mathrm{mM}$ dNTP mix (Cinna Gen Co, Iran), $0.2 \mu \mathrm{M}$ of a single primer, 15-40 ng of template DNA, and $1 \mathrm{U}$ of Taq DNA polymerase (Cinna Gen $\mathrm{Co}$, Iran). The amplification reactions for both assays were performed with a T100 thermocycler (BIORAD, USA).

For DAMD assay, all amplification were carried out as follows: $94^{\circ} \mathrm{C}$ for $5 \mathrm{~min}$, followed by 40 cycles of denaturation at $94^{\circ} \mathrm{C}$ for $1 \mathrm{~min}$, annealing at $55^{\circ} \mathrm{C}$ for $1 \mathrm{~min}$, and extension at $72^{\circ} \mathrm{C}$ for $90 \mathrm{sec}$. A final extension cycle at $72^{\circ} \mathrm{C}$ for $10 \mathrm{~min}$ was followed. The amplification reactions of SCoT were performed with the following program: 5 min initial denaturation at $94^{\circ} \mathrm{C}$ followed by 36 cycles of $1 \mathrm{~min}$ at $94^{\circ} \mathrm{C}$, annealing at $57.5^{\circ} \mathrm{C}$ for $1 \mathrm{~min}$, and $90 \mathrm{~s}$ at $72^{\circ} \mathrm{C}$. The reaction was completed by a final extension step of $10 \mathrm{~min}$ at $72^{\circ} \mathrm{C}$.

The amplification products were visualised by electrophoresis in $1 \%(\mathrm{w} / \mathrm{v})$ agarose gels, followed by $0.5 \mu \mathrm{g} / \mathrm{ml}$ powerload staining. Fragment sizes were estimated using a $100 \mathrm{bp}$ size ladder (Fermentas, Germany), photographed under UV light and scored for the presence or absence of bands. 
Table 2. Summary of leaf features of Circaea lutetiana populations observed under scanning electron microscopy. Pop (forest populations): HJ (Hezarjerib), LA (Lavij), LI (Liresar), MA (Masoleh), NA (Naharkhoran), SA (Sangdeh), SH (Shastkalateh), ZI (Zirab), ZY (Zyarat). Guard cells shape: E (elliptic), NE (narrow elliptic), WE (wide elliptic). Ridges: HR (heavily ridged), NR (normally ridged), SR (slightly ridged). Striations: CS (coarsely striate), NS (normally striate), RS (striations rarely found), SS (slightly striate). Stomatal pole: T (truncate), Tp (“T” pieces). L/W: long/width. Stomatal rim location: L (level to guard cell), NL (nearly level to guard cell), R (raised). Outer surface guard cells: FS (finely striate), NST (normally striate), C (crustose).

\begin{tabular}{|c|c|c|c|c|c|c|c|}
\hline Pop & $\begin{array}{l}\text { Guard cells } \\
\text { shape }\end{array}$ & Pristomatal rim & $\begin{array}{l}\text { Cuticular } \\
\text { membrane }\end{array}$ & Stomatal pole & $\mathbf{L} / \mathbf{W}$ & $\begin{array}{l}\text { Stomatal rim } \\
\text { location }\end{array}$ & $\begin{array}{l}\text { Outer surface } \\
\text { guard cells }\end{array}$ \\
\hline $\mathrm{SH}$ & WE & Absent & $\mathrm{SR}, \mathrm{CS}$ & $\mathrm{T}$ & 1.40 & NL & FS \\
\hline HJ & $\mathrm{NE}$ & Present & $\mathrm{SR}, \mathrm{SS}$ & $\mathrm{T}$ & 1.50 & NL & FS \\
\hline LA & $\mathrm{E}$ & Present & NR, RS & $\mathrm{T}$ & 1.34 & $\mathrm{~L}$ & NST \\
\hline LI & $\mathrm{E}$ & Present & NR, RS & $\mathrm{T}$ & 1.27 & $\mathrm{R}$ & NST \\
\hline MA & NE & Present & HR, RS & $\mathrm{Tp}$ & 1.54 & $\mathrm{R}$ & FS \\
\hline NA & $\mathrm{E}$ & Absent & NR, NS & $\mathrm{T}$ & 1.37 & $\mathrm{R}$ & $\mathrm{C}$ \\
\hline SA & $\mathrm{E}$ & Absent & NR, RS & $\mathrm{Tp}$ & 1.50 & NL & FS \\
\hline ZI & $\mathrm{E}$ & Absent & SR, CS & $\mathrm{Tp}$ & 1.53 & $\mathrm{~L}$ & FS \\
\hline ZY & WE & Present & $\mathrm{SR}, \mathrm{RS}$ & $\mathrm{T}$ & 1.32 & $\mathrm{R}$ & $\mathrm{C}$ \\
\hline
\end{tabular}

\section{Data analysis}

The morphological features were standardized (Mean $=0$, Variance $=1)$ and used to establish the Euclidean distance among taxa pairs (Podani 2000). The obtained distances were used for clustering. The Ward method of hierarchical cluster analysis (Podani 2000) was used for grouping the plant specimens based on the Euclidean distance. Alongside, PCA (principal components analysis) was carried out to identify the most variable morphological features (Podani 2000). PAST v. 2.17 (Hammer \& al. 2001) was used for the above analyses.

The obtained SCoT and DAMD bands were coded as binary characters (presence $=1$, absence $=0$ ). The genetic diversity parameters like allele diversity (Weising \& al. 2005), Nei's gene diversity (H), Shannon information index (I), the number of effective alleles, and percentage of polymorphism (Freeland \& al. 2011) were determined using the GenAlex v. 6.4 software in each population for a dominant molecular marker (Peakall \& Smouse 2006). Nei's genetic distance was used for clustering (Weising $\&$ al. 2005; Freeland \& al. 2011). Neighbour Joining (NJ) clustering was used for grouping (Freeland \& al. 2011) after 100 times bootstrapping. The NJ tree with the Dice coefficient showed a better grouping than one done with the Jaccard coefficient. PAST and GenAlex were used for these analyses. Genetic differentiation of the studied specimens and populations was studied by AMOVA (analysis of molecular variance) test (with 1000 permutations) as performed in GenAlex v. 6.4 (Peakall \& Smouse 2006).

Genetic admixture among populations was analyzed by model-based clustering as performed by STRUCTURE v. 2.3 (Pritchard \& al. 2000). We used the admixture ancestry model under the correlated allele frequency model. Data were scored as dominant markers and analysis followed the method suggested by (Falush \& al. 2007). Indirect evaluation of the gene flow (Whitlock \& McCauley 1999) among populations was checked by reticulation analysis in the DARwin v. 5.0 (Perrier \& Jacquemoud-Collet 2006) with a reticulation tree.

A Mantel test was performed to check for correlation between geographical and genetic distances of the studied populations (Podani 2000). PAST v. 2.17 (Hammer \& al. 2001) and Genealex v. 6.4 (Peakall \& Smouse 2006) were used for these analyses. The Pearson coefficient of correlation was determined between geographical features (longitude and latitude) and genetic diversity parameters. A canonical correspondence analysis (CCA) was done using PAST v. $2.17 \mathrm{c}$ (Hammer \& al. 2001), to determine the relative importance of geographical factors in the spatial organization of genetic diversity among genotypes.

\section{RESULTS}

\section{Macro- and micro-morphological assay}

In total 23 macro (see material methods section) and micro-morphological characteristics of Circaea lutetiana populations were studied (see leaf SEM features in Table 2). Among them 17 features were selected based on PCA-biplot (Fig. 1). PCA analysis of morphological features revealed that the first three PCA components comprised about $70.38 \%$ of the total variability of the studied populations. In the first PCA axis with about $33 \%$ of the total variation, morphological traits like the stomatal pole, leaf-base shape, petal color possessed the highest correla- 
Table 3. Genetic diversity parameters of the studied populations. PPB (genetic polymorphism percentage), Na (mean number of different alleles over all loci), Ne (mean number of effective alleles), I (Shannon Index), He (gene diversity), Uhe (unbiased expected heterozygosity), SCoT (start codon targeted), DAMD (direct amplification of minisatellite DNA), S\&D (SCoT \& DAMD). Forest populations (Pop): HJ (Hezarjerib), LA (Lavij), LI (Liresar), MA (Masoleh), NA (Naharkhoran), SA (Sangdeh), SH (Shastkalateh), ZI (Zirab), ZY (Zyarat).

\begin{tabular}{llllllllll}
\hline & \multicolumn{3}{c}{ PPB\% } & \multicolumn{3}{c}{ Na } & \multicolumn{2}{c}{ Ne } \\
\cline { 2 - 10 } Pop & SCoT & DAMD & S\&D & SCoT & DAMD & S\&D & SCoT & DAMD & S\&D \\
\hline SA & 47.56 & 30 & 40.54 & $1.01 \pm 0.1$ & $0.7 \pm 0.1$ & $0.89 \pm 0.07$ & $1.31 \pm 0.04$ & $1.23 \pm 0.04$ & $1.28 \pm 0.03$ \\
NA & 47.56 & 37.14 & 43.99 & $1.03 \pm 0.1$ & $0.78 \pm 0.1$ & $0.94 \pm 0.08$ & $1.3 \pm 0.04$ & $1.3 \pm 0.05$ & $1.31 \pm 0.03$ \\
LI & 26.83 & 28.57 & 28.38 & $0.59 \pm 0.09$ & $0.62 \pm 0.1$ & $0.62 \pm 0.07$ & $1.17 \pm 0.03$ & $1.26 \pm 0.05$ & $1.23 \pm 0.03$ \\
ZY & 39.02 & 44.29 & 42.57 & $0.84 \pm 0.1$ & $0.97 \pm 0.1$ & $0.92 \pm 0.07$ & $1.23 \pm 0.03$ & $1.36 \pm 0.05$ & $1.3 \pm 0.03$ \\
SH & 35.37 & 30 & 33.78 & $0.81 \pm 0.1$ & $0.68 \pm 0.1$ & $0.77 \pm 0.07$ & $1.24 \pm 0.04$ & $1.23 \pm 0.04$ & $1.24 \pm 0.03$ \\
LA & 52.44 & 47.14 & 51.35 & $1.08 \pm 0.1$ & $1.07 \pm 0.1$ & $1.1 \pm 0.07$ & $1.36 \pm 0.04$ & $1.31 \pm 0.04$ & $1.35 \pm 0.03$ \\
HJ & 40.24 & 47.14 & 44.59 & $0.84 \pm 0.1$ & $1.02 \pm 0.1$ & $0.95 \pm 0.08$ & $1.2 \pm 0.04$ & $1.25 \pm 0.04$ & $1.23 \pm 0.02$ \\
MA & 31.71 & 58.57 & 45.27 & $0.7 \pm 0.1$ & $1.22 \pm 0.1$ & $0.97 \pm 0.08$ & $1.19 \pm 0.03$ & $1.32 \pm 0.04$ & $1.26 \pm 0.02$ \\
ZI & 34.15 & 40 & 36.49 & $0.8 \pm 0.1$ & $0.94 \pm 0.1$ & $0.86 \pm 0.07$ & $1.23 \pm 0.04$ & $1.26 \pm 0.04$ & $1.25 \pm 0.03$ \\
Total & 39.43 & 40.32 & 40.77 & $0.86 \pm 0.03$ & $0.89 \pm 0.03$ & $0.89 \pm 0.02$ & $1.25 \pm 0.01$ & $1.28 \pm 0.01$ & $1.27 \pm 0.01$ \\
\hline
\end{tabular}

Table 3. Cont.

\begin{tabular}{|c|c|c|c|c|c|c|c|c|c|}
\hline \multirow[b]{2}{*}{ Pop } & \multicolumn{3}{|c|}{ I } & \multicolumn{3}{|c|}{$\mathrm{He}$} & \multicolumn{3}{|c|}{ UHe } \\
\hline & SCoT & DAMD & S\&D & SCoT & DAMD & S\&D & SCoT & DAMD & S\&D \\
\hline SA & $0.26 \pm 0.03$ & $0.18 \pm 0.03$ & $0.23 \pm 0.02$ & $0.18 \pm 0.02$ & $0.12 \pm 0.02$ & $0.16 \pm 0.01$ & $0.2 \pm 0.02$ & $0.14 \pm 0.02$ & $0.17 \pm 0.01$ \\
\hline NA & $0.26 \pm 0.03$ & $0.23 \pm 0.03$ & $0.25 \pm 0.02$ & $0.17 \pm 0.02$ & $0.16 \pm 0.02$ & $0.17 \pm 0.01$ & $0.19 \pm 0.02$ & $0.18 \pm 0.03$ & $0.19 \pm 0.01$ \\
\hline LI & $0.14 \pm 0.02$ & $0.19 \pm 0.03$ & $0.17 \pm 0.02$ & $0.1 \pm 0.02$ & $0.13 \pm 0.02$ & $0.12 \pm 0.01$ & $0.11 \pm 0.02$ & $0.15 \pm 0.02$ & $0.13 \pm 0.01$ \\
\hline ZY & $0.21 \pm 0.03$ & $0.27 \pm 0.03$ & $0.24 \pm 0.02$ & $0.14 \pm 0.02$ & $0.19 \pm 0.02$ & $0.16 \pm 0.01$ & $0.15 \pm 0.02$ & $0.21 \pm 0.03$ & $0.18 \pm 0.01$ \\
\hline $\mathrm{SH}$ & $0.2 \pm 0.03$ & $0.18 \pm 0.03$ & $0.19 \pm 0.02$ & $0.13 \pm 0.02$ & $0.12 \pm 0.02$ & $0.13 \pm 0.01$ & $0.15 \pm 0.02$ & $0.14 \pm 0.02$ & $0.15 \pm 0.01$ \\
\hline LA & $0.29 \pm 0.03$ & $0.26 \pm 0.03$ & $0.29 \pm 0.02$ & $0.2 \pm 0.02$ & $0.18 \pm 0.02$ & $0.29 \pm 0.01$ & $0.22 \pm 0.02$ & $0.2 \pm 0.02$ & $0.21 \pm 0.01$ \\
\hline HJ & $0.2 \pm 0.02$ & $0.23 \pm 0.03$ & $0.22 \pm 0.02$ & $0.13 \pm 0.01$ & $0.15 \pm 0.02$ & $0.14 \pm 0.01$ & $0.14 \pm 0.02$ & $0.17 \pm 0.02$ & $0.16 \pm 0.01$ \\
\hline MA & $0.17 \pm 0.02$ & $0.29 \pm 0.03$ & $0.23 \pm 0.02$ & $0.11 \pm 0.02$ & $0.19 \pm 0.23$ & $0.15 \pm 0.01$ & $0.12 \pm 0.2$ & $0.21 \pm 0.02$ & $0.17 \pm 0.01$ \\
\hline ZI & $0.19 \pm 0.03$ & $0.22 \pm 0.03$ & $0.2 \pm 0.02$ & $0.13 \pm 0.02$ & $0.15 \pm 0.02$ & $0.14 \pm 0.01$ & $0.14 \pm 0.02$ & $0.16 \pm 0.02$ & $0.15 \pm 0.01$ \\
\hline Total & $0.21 \pm 0.01$ & $0.23 \pm 0.01$ & $0.23 \pm 0.008$ & $0.14 \pm 0.007$ & $0.15 \pm 0.008$ & $0.15 \pm 0.006$ & $0.16 \pm 0.008$ & $0.17 \pm 0.009$ & $0.17 \pm 0.006$ \\
\hline
\end{tabular}

tion while in the second PCA axis, characters like seed trichomes, ridge pattern of the cuticular membrane, and stomatal rim location; in the third PCA axis characters like leaf margin and stigma notch possessed the highest correlation. Therefore, these morphological characters were the most variable morphological characteristics among the studied populations. PCA-biplot of morphological characters (Fig.1) separated the populations studied into distinct groups. It also showed that the HJ specimen was differentiated from the other populations due to its seed trichomes, while the SA, ZI, and MA specimens were differentiated from the others due to the "T-pieces" feature of the stomatal pole and petal color (white-pink to pink) (Fig. 3).
Based on macro and micro-morphological traits, the studied specimens were separated in the Ward tree of morphological features (Fig. 2). Two main branches resulted. One included four populations arranged in two sub-groups: subgroup I, including SA and ZI, subgroup II including MA and NA. The rest of the populations were placed in another branch, which also had two sub groups: populations HJ became detached from others and placed in one sub-branch. As seen in the PCA biplot (Fig. 1), each of the studied populations showed distinct morphological trait(s). The leafbase shape was truncate to truncate-cuneate in the ZI, SA, and NA populations, while the others had a round-truncate leaf base. Petal color was white-pink to pink in HJ, ZI, SA, 


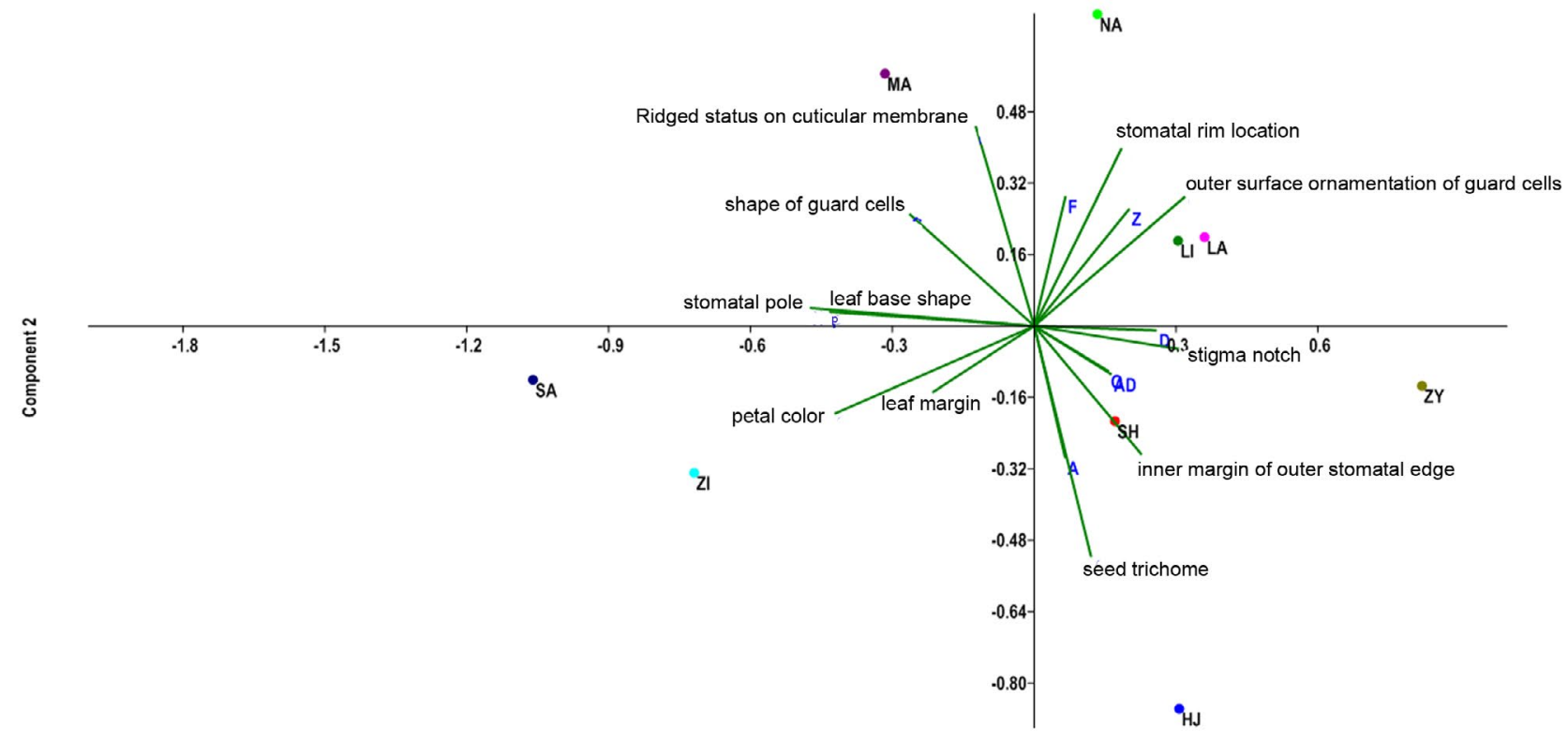

Component 1

Fig. 1. Principal components analysis (PCA)-biplot based on macro- and micro-morphological features of Circaea lutetiana. Forest populations: HJ (Hezarjerib), LA (Lavij), LI (Liresar), MA (Masoleh), NA (Naharkhoran), SA (Sangdeh), SH (Shastkalateh), ZI (Zirab), ZY (Zyarat). A (ornamentation of outer stomatal edge), D (Peristomatal rim), F (striation status on the cuticular membrane), P (shape of leaf base), Z (length of seed tip), AD (leaf length/ petiole length).

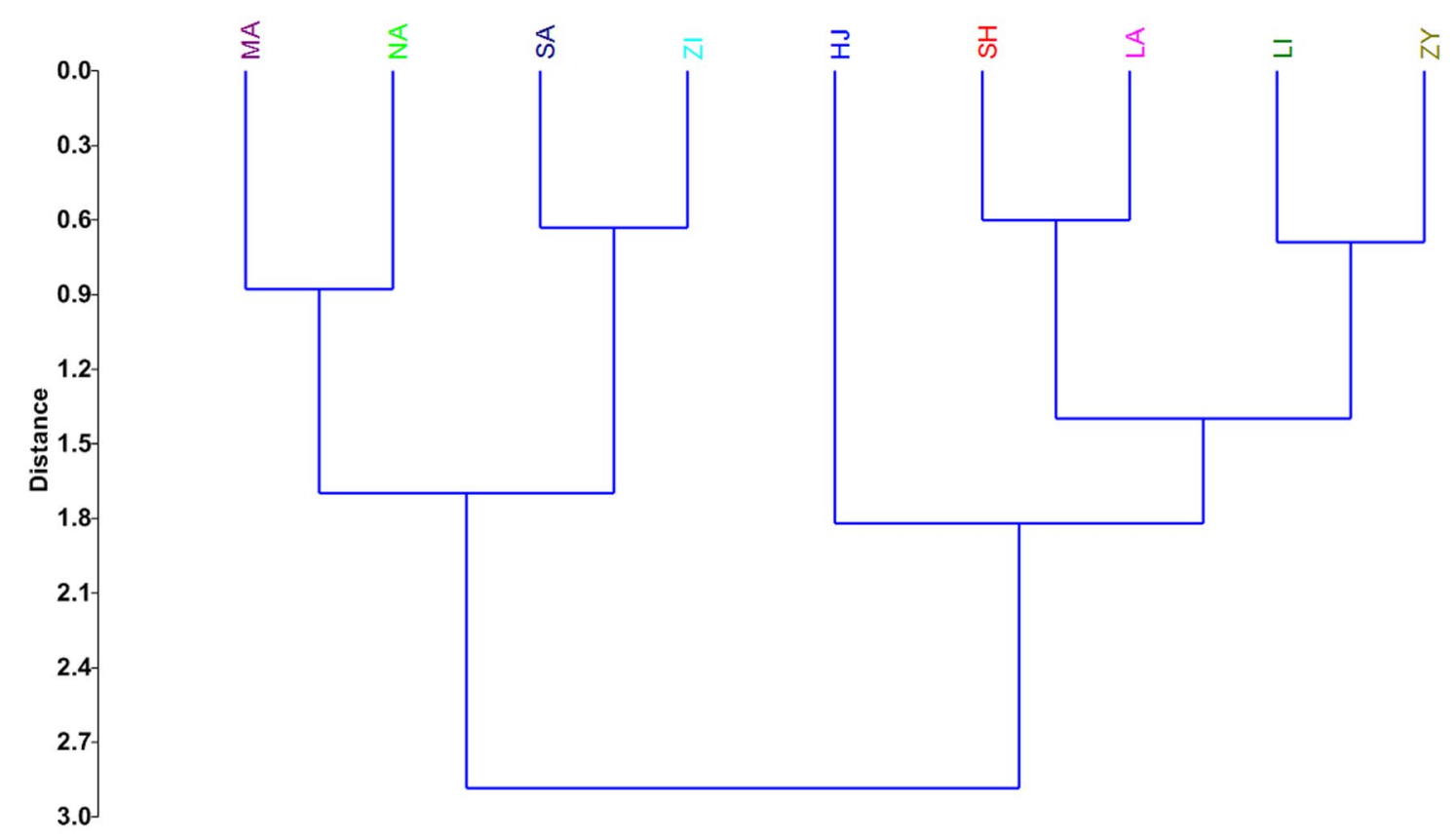

Fig. 2. Ward dendrogram based on macro/micro- morphological features of Circaea lutetiana. Forest populations: HJ (Hezarjerib), LA (Lavij), LI (Liresar), MA (Masoleh), NA (Naharkhoran), SA (Sangdeh), SH (Shastkalateh), ZI (Zirab), ZY (Zyarat). 

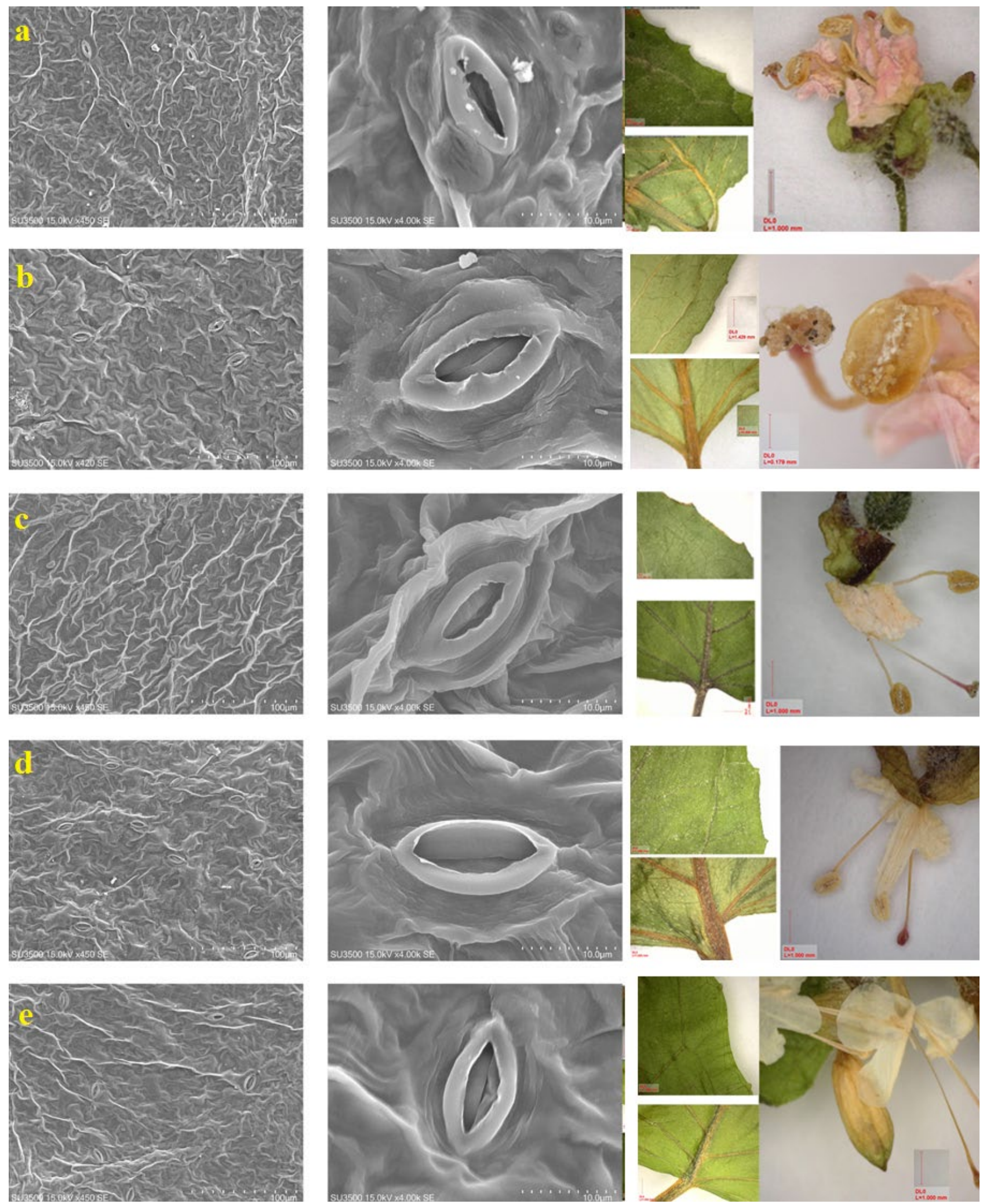

Fig. 3. Scanning electron microscopy (SEM) micrographs (flower and leaf) of Circaea lutetiana specimens from the studied forest populations: a, Sangdeh; b, Zirab; c, Masoleh; d, Naharkhoran. Figure continues (next page). 

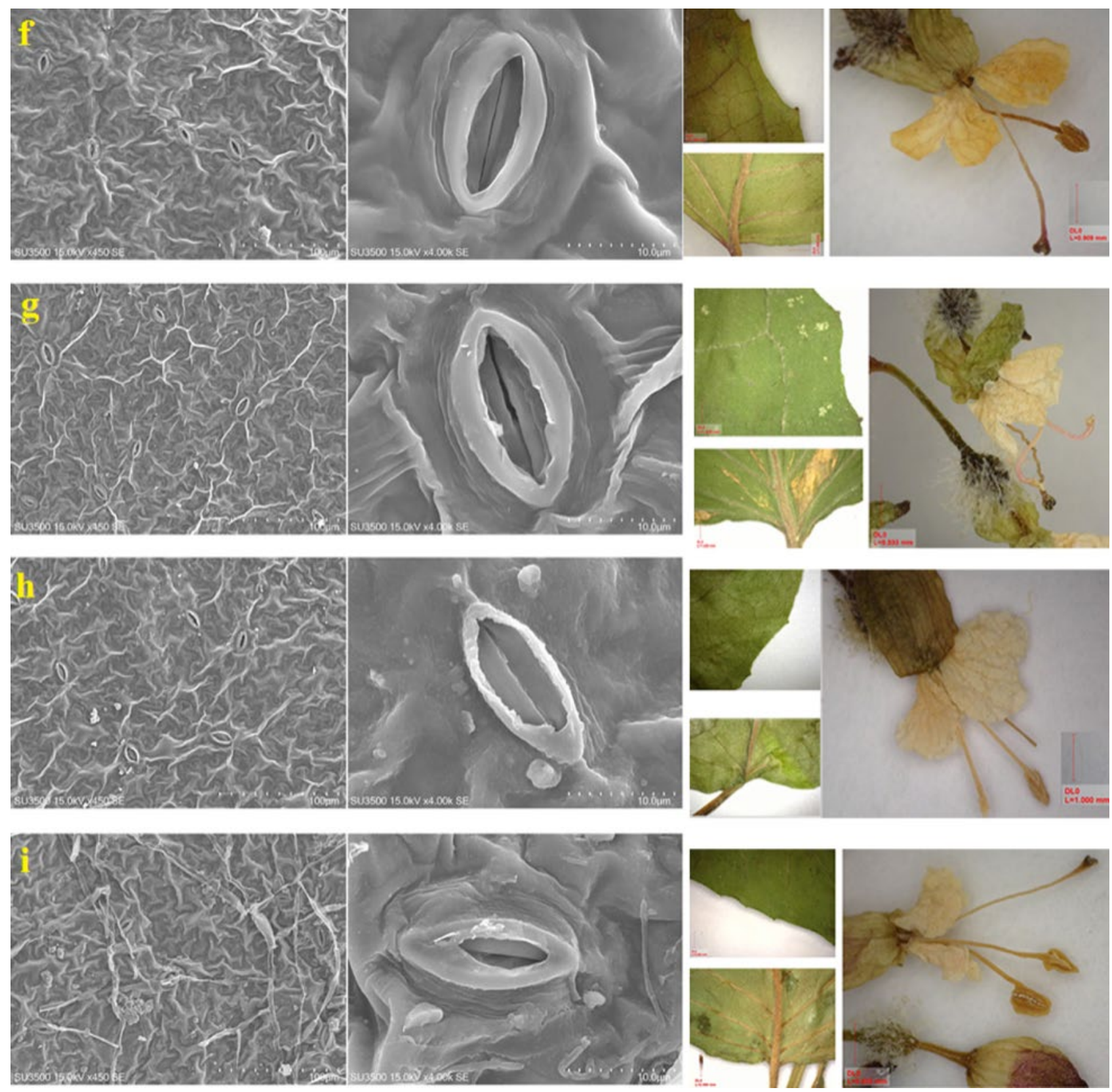

Fig. 3. (continued) Scanning electron microscopy (SEM) micrographs (flower and leaf) of Circaea lutetiana specimens from the studied forest populations: e, Shast-kalate; f, Lavij; g, Liresar; h, Zyarat; i, Hezar-jerib.

MA, and white in the other populations. Considering the measurement of denticulation of leaf margin, there were three groups: slightly denticulate (HJ, MA, NA), denticulate (LI, LA, SH, ZY), and heavily denticulate (ZI, SA). The notching on stigma was deeper in $\mathrm{ZY}, \mathrm{LA}, \mathrm{SH}$, and lower in the other populations. This classification does not agree with geographical distance. Although morphological variation was observed within the population, we tried to consider the average of traits in the population. In the studied specimens, there were two types of stigma knotch including deeply (in ZY, LA, SH) and shallowly (Fig. 3h,
$3 \mathrm{f}, 3 \mathrm{e})$ knotched. In all populations, except for populations HJ, MA, ZI, and SA, whose petals were white-pink or pink in color, the petals were completely white (Fig. 3i, 3c, 3b, 3a). As seen in Fig. 3 leaf-margin of the specimens showed three character states including slightly denticulate (in HJ, MA, NA; Fig. 3i, 3c, 3d), denticulate (LA, LI, ZY, SH; Fig. $3 \mathrm{f}, 3 \mathrm{~g}, 3 \mathrm{~h}, 3 \mathrm{e}$ ) to heavily denticulate (ZI, SA; Fig. 3b, 3a). The following two main types of epidermis were recognized. Type I (Ia: SA, ZI and Ib: SH, HJ) had a fine striation on the outer surface of guard cell and slight to normal ridged on the cuticular membrane. In type I the stomatal 


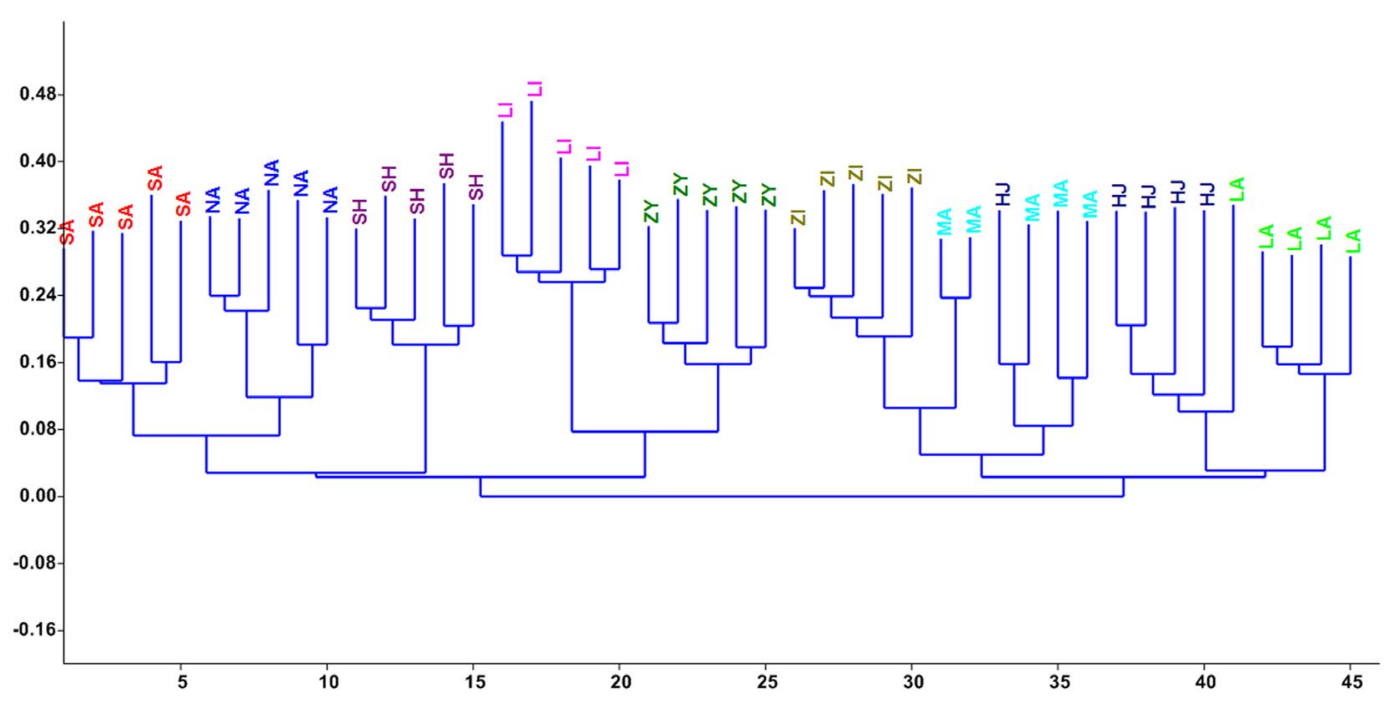

Fig. 4. Neighbor Joining tree of Start Codon Targeted (ScoT) and direct amplification of minisatellite DNA (DAMD) data using Dice genetic distance of the studied Circaea lutetiana populations. Forest populations: HJ (Hezarjerib), LA (Lavij), LI (Liresar), MA (Masoleh), NA (Naharkhoran), SA (Sangdeh), SH (Shastkalateh), ZI (Zirab), ZY (Zyarat).

rim was located nearly to the epidermal surface (Fig. 3a, 3b, 3e, 3i). Type II (IIa: NA, ZY and IIb: MA, LI, LA) had normal striation on outer surface of guard cells and rarely exhibited striations on the cuticular membrane. In this type the stomatal rim was raised in relation to the surface of the epidermis (Fig. 3d, 3h, 3c, 3g, 3f).

\section{Genetic diversity}

The amplification of primers 4 SCoT and 4 DAMD resulted in 148 bands. The genetic diversity parameters related to the studied populations are shown in Table 3 . The highest values for the mean number of effective alleles $(\mathrm{Ne}=1.36$, $1.31)$ and gene diversity $(\mathrm{He}=0.2,0.18)$ were in populations LA and SA, respectively. These populations also showed the highest values for the genetic polymorphism percentage $(52.44,47.54)$. The lowest values for the mean number of the effective alleles and gene diversity occurred in $\mathrm{LI}(\mathrm{Ne}$ $=1.23, \mathrm{He}=0.12)$ and $\mathrm{SH}(\mathrm{Ne}=1.24, \mathrm{He}=0.13)$. These populations showed the lowest values for the genetic polymorphism percentage $(28.38,33.78)$. The mean number of different alleles over all loci $(\mathrm{Na})$ ranged between $0.62(\mathrm{LI})$ 1.1 (LA). Shannon's information index ranged between 0.17 (LI)-0.29 (LA).

The AMOVA results indicated significant molecular difference $(F P T=0.46, \mathrm{P}=0.01)$ among populations indicating a great level of genetic differentiation. It also revealed that $46 \%$ of the total genetic diversity was related to inter-population differences, while $54 \%$ was related to intra-population differences.

The Dice distances between pairs of populations were calculated based on the 148 analysed bands. The Neighbor Joining (NJ) dendrogram (Fig. 4) consisted of two major clusters each containing two subclusters. Populations LA, HJ nested within subcluster 1 and MA and ZI occurred in subcluster 2 of first main cluster. The members of populations ZY and LI formed subcluster 1, while populations $\mathrm{SH}, \mathrm{SA}, \mathrm{NA}$ occurred in subcluster 2 of the second major cluster.

\section{Population structure and gene flow}

The Mantel test revealed no significant correlation ( $\mathrm{r}=$ $0.02, \mathrm{p}=0.5$ ) between genetic distance and geographical distance (Fig. 5). According to the Evanno's method, the STRUCTURE analysis indicated $\mathrm{K}=3$ as the most likely number of gene pools. A STRUCTURE plot based on $\mathrm{k}=$ 3 is shown in Fig. 6. In general, populations SA, NA and $\mathrm{SH}$ were genetically more alike and form the first genetically similar group. The same holds true for populations LI, ZY which compose the second group. Populations LA, HJ, MA, and ZI formed the third genetic group. Some of the populations were highly genetically discrete ( $\mathrm{SA}, \mathrm{SH}$, NA ZY, LI, ZI), while the others showed a high degree of genetic admixture due to common ancestral alleles (MA, LA, HJ). This Bayesian approach analysis was in accor- 


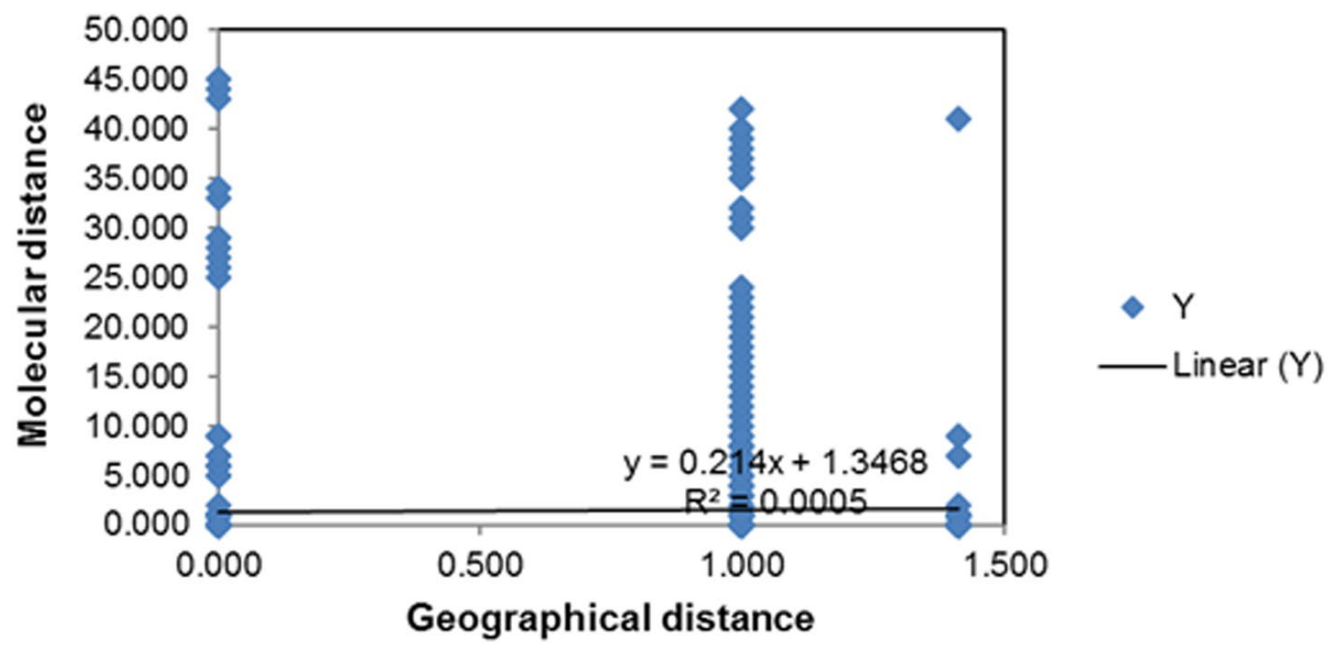

Fig. 5. Mantel test plot of genetic distance versus geographical distance among the studied populations of Circaea lutetiana.

dance with NJ tree and PCA plot. The reticulation method of networking agreed with the least square method and determined similar/shared alleles between populations. Also, the reticulogram plot (Fig. 7) indicated a limited degree of gene flow among populations HJ-MA, LA-LI, and ZI-ZY. None of these three pairs are located at close geographical distance between each other.

\section{Environmental factors and genetic diversity}

The CCA analysis was used to investigate the influence of environmental factors on the differentiation of populations. According to the CCA plot (Fig. 8), the environmental features of the different habitats affected population's aggregation (Axis $1=45.18 \%$ of variance; Axis $2=31.78$ $\%)$. The clustering of LA, HJ, NA, SH, and SA populations was influenced by mean annual temperature (AMT). Within this group mean annual rainfall (AP) separated $\mathrm{SH}$ and SA populations from the others. The clustering of $\mathrm{ZI}$ and MA was influenced by humidity. Elevation influenced the grouping of LI and ZY.

\section{DISCUSSION}

According to the results of the Mantel and STRUCTURE analyses, genetic differentiation among studied populations of Circaea lutetiana was not related to geographic distance. We could see a clear genetic split between neighboring populations, for example MA and LI, $\mathrm{ZI}$ and SA, HJ and SH, ZY and NA. Moreover, there are populations with similar genetic structure but geographically distant (LI and ZY; MA and ZI; HJ and LA). The absence of isolation-by-distance strongly indicates that gene flow between populations is infrequent (Hamasha \& al. 2013).
Gene flow between populations happens either by seed or pollen dispersal or both (Cain \& al. 2000; Robertson \& al. 2008). Given that seed dispersal is often found to be spatially restricted (Struik 1965), the gene flow into plant populations is mainly dependent on pollen dispersal (Bacles \& Ennos 2008). We assume that environmental heterogeneity of the populations might have limited the pollen dispersal and consequently gene flow between populations. Apart of the effect of gene flow on the differentiation of populations, a trade-off between vegetative propagation and sexual reproduction, or both modes, could have existed in this pseudo-annual clonal plant (Verburg \& During 1998).

The strong effects of environmental variation and microhabitat differences on the branches of rhizomes, seedling recruitment, size and number of hibernacles, genet size and weight could be expected (Verburg \& al. 1996; Verburg \& During 1998; Verburg \& al. 2000). Verburg $\&$ al. (2000), in their study on clonal diversity in differently-aged populations of Circaea lutetiana using RAPD marker, found high genet diversity due to micro-site specialization. Our results indicate that in the populations with similar genetic structure but geographically distant, the strong selection to seedling recruitment by micro-habitat differences could be evidenced.

The environmental heterogeneity of habitats can cause intense variation in flowering time among adjacent populations depending on their altitude, amount of sun exposure, humidity, temperature, and vegetation density (Cortés \& al. 2013; Duarte \& al. 2015). Phenological variations in flowering set and flowering period can limit the pollen exchange and therefore decrease the degree of gene flow among populations (Franks \& Weis 2009). Such kind of reproductive isolation may have contributed to the limitation of gene flow 

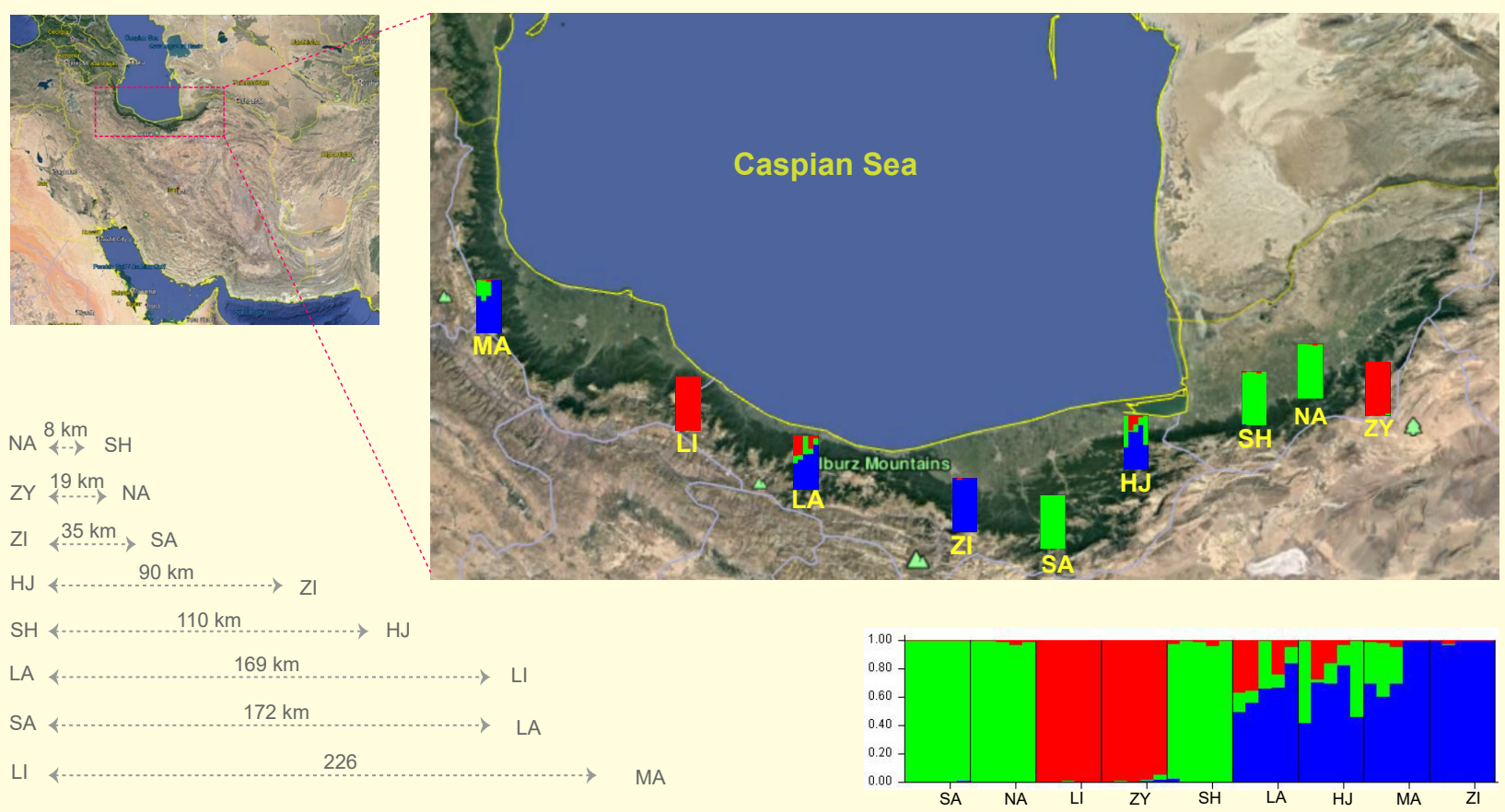

Fig. 6. Map of the studied populations of Circaea lutetiana in northern Iran. The bars indicate different gene pools from the genetic structure analysis (best fit model, $\mathrm{K}=3$ ). Each color represents a different gene pool. Forest populations: HJ (Hezarjerib), LA (Lavij), LI (Liresar), MA (Masoleh), NA (Naharkhoran), SA (Sangdeh), SH (Shastkalateh), ZI (Zirab), ZY (Zyarat).

and consequent genetic differentiation of geographically adjacent populations of Circaea lutetiana. Moreover, Verburg \& During (1998) indicated the plasticity of the phenology, developmental rate of plants growing and flowering time of the species in different light treatments.

The NJ tree and Bayesian STRUCTURE analyses revealed that populations of Circaea lutetiana in the Hyrcanian region of Iran grouped in three different clusters. According to the CCA results, the genetic clustering of the populations is related to the similarity in microclimate conditions. The first cluster comprises the LI and ZY populations that are located far away towards the west and east of the Hyrcanian region. In the CCA results, both are separated from the rest of the populations due to their high elevation.

The second cluster comprises the SH, SA and NA populations, with a similar gene pool. According to CCA analysis, these populations are distinguished by their average annular rainfall that is the lowest among all populations. The four remained populations including LA, HJ, ZI and MA fall into the third cluster. Within this cluster, the ZI and MA populations are characterized by the relatively cool temperature and high level of humidity (along river bank), while the LA and HJ populations belong to the habitats with the highest average annual temperature. The two last populations show the most admixed genetic pool among the studied populations.

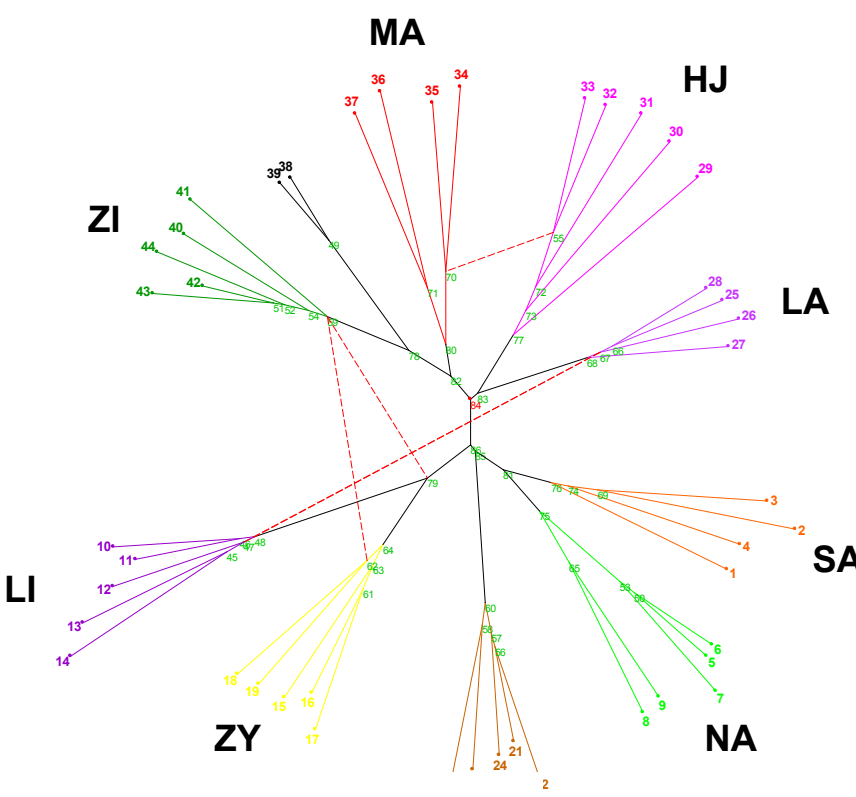

SH

Fig. 7. Reticulation tree based on Nei's genetic distance of the studied populations of Circaea lutetiana (values above nodes are bootstrap values). Forest populations: HJ (Hezarjerib), LA (Lavij), LI (Liresar), MA (Masoleh), NA (Naharkhoran), SA (Sangdeh), SH (Shastkalateh), ZI (Zirab), ZY (Zyarat). 


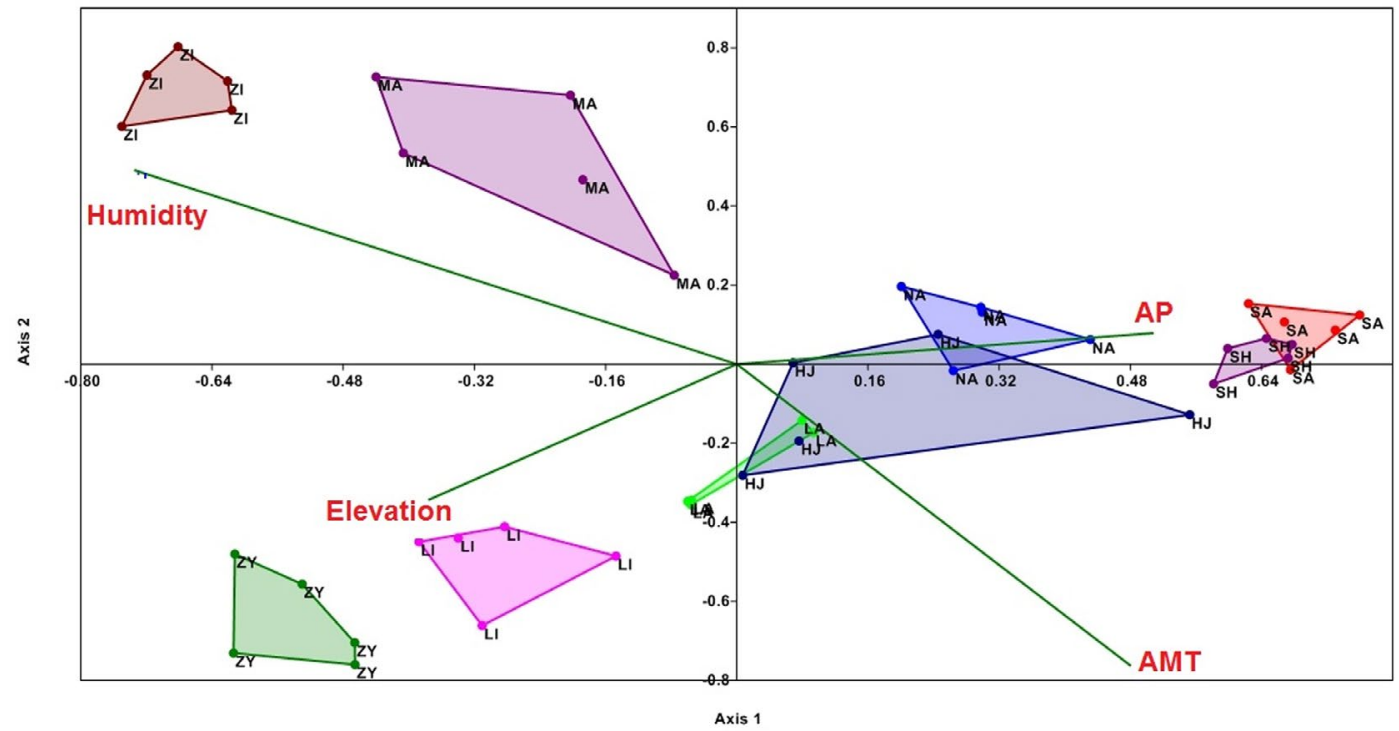

Fig. 8. Canonical correspondence analysis (CCA) biplot representing population aggregation and environmental factors (solid arrows) in Circaea lutetiana . The CCA explained 43.09 and $35.01 \%$ of the variation on the first two axes. AMT (mean annual temperature), AP (mean annual rainfall). Forest populations: HJ (Hezarjerib), LA (Lavij), LI (Liresar), MA (Masoleh), NA (Naharkhoran), SA (Sangdeh), SH (Shastkalateh), ZI (Zirab), ZY (Zyarat).

Regarding the environmental features of the clusters, in disturbed areas the populations may be younger and seedling recruitment can increase the genetic diversity (i.e. LA, HJ, MA, but not ZY and ZI). In accordance with Verburg $\&$ al. (2000) study, the high genetic diversity in the LA, HJ, and MA populations may be due to habitat disturbance (caused by forest road) and recolonization of young ramets in empty patches. Based on Verburg \& al. (2000) the empty patches due to disturbance could be increase genet diversity and genet size distributions.

All populations in deep, dark and dense forests (LI, NA, SA, SH) show low genetic diversity and maybe clonal reproduction by hibernacles of older genets effectively compete avoiding seedling recruitment. The phenotypic responses to various environments may also consist of highly special physiological, developmental as well as reproductive adaptations that improve plant function in those environments (Bradshaw 1965; Schmitt \& al. 1999).

Based on Losos \& Glor (2003) opinion, the formation of new taxonomic ranking depends on the morphological variation and geographical separation among population. Both morphological and genetic similarities of the two pair of populations including MA, ZI and LI, ZY may indicate that cryptic speciation under the influence of microclimate factors are occurring in different geographical locations.

Thus, the populations belonging to each of the three clusters have similarities in terms of microclimate parameters, despite their geographical proximity, and the population from the same genetic cluster can be up to $470 \mathrm{~km}$ apart (e.g. MA and ZI or LI and ZY). We therefore suggest that environmental heterogeneity has shaped the morphological and structural diversity of Circaea lutetiana in Hyrcanian forests. A similar study on Camisonia benitensis P.H.Raven (Onagraceae) with microsatellite markers, indicated evidence of cryptic genetic subdivision that did not correlate with habitat type, watershed, or physical distance between populations and populations from the same genetic cluster can be up to $29 \mathrm{~km}$ distant from one another (Dick \& al. 2014).

It is well-known that the populations of a given species facing different environmental conditions may undergo genetic changes to adapt to their local conditions (Hufford $\&$ Mazer 2003) (Khan \& al. 2015). Such adaptive genetic changes are often fixed within population through natural selection resulting in multiple, genetically distinct populations within a single species (Antonovics \& Bradshaw 1970; Slatkin 1985; Mitton \& al. 1997; Khan \& al. 2015). There are a multitude of plant adaptations for tolerating or capitalizing on environmental heterogeneity. When the environmental heterogeneity is related to the availability of plant resource like water, light, and nutrients, it can directly affects rates of resource uptake, and thus growth, reproduction, and survivorship. On the other hand, heterogeneity in physical parameters like temperature, humidity, and wind speed may affects the plant function by modifying metabolic rates, stomatal control, or morphology, genet size and weight, phenology, flowering time, seedling recruitment, and thus resource processing (Fox \& al. 2012; Verburg \& During 1998; Verburg \& al. 2000). 


\section{CONCLUSION}

SCoT and DAMD analyses revealed significant genetic differentiation among the studied populations. However, the Mantel test showed no correlation between genetic distance and geographical distance. Moreover, with regard to macro/micro-morphological features, similar results were observed. Our study indicates that local adaptation to microhabitats played the most important role in the diversification of Circaea lutetiana populations in the Hyrcanian region of Iran. This may indicate the presence of cryptic species or subspecies in C. lutetiana, but a more thorough molecular study based on sequence markers is needed to confirm that conclusion. From a conservation perspective, given the positive and strong correlation between the genetic differentiation and environmental heterogeneity, the maintenance of populations in each region is crucial to ensure the preservation of genetic diversity in this species.

\section{ACKNOWLEDGMENTS}

We thank Saeed Javadi Anaghizi (Central Laboratory of the Shahid Beheshti University, Tehran, Iran) for providing SEM photographs.

\section{REFERENCES}

Ahmad P. \& Prasad M.N.V. 2011. Abiotic stress responses in plants. metabolism, productivity and sustainability. Springer, New York.

Akhani H., Djamali M., Ghorbanalizadeh A. \& Ramezani E. 2010. Plant biodiversity of Hyrcanian relict forests, N Iran: an overview of the flora, vegetation, palaeoecology and conservation. Pakistan Journal of Botany 42 (Special Issue): 231-258.

Antonovics J. \& Bradshaw A.D. 1970. Evolution in closely adjacent plant populations. VIII. Glinal patterns at a mine boundary. Heredity 25: 349-362.

Bacles C.F. \& Ennos R.A. 2008. Paternity analysis of pollen-mediated gene flow for Fraxinus excelsior L. in a chronically fragmented landscape. Heredity 101: 368-380.

Boufford D.E. 2005. Circaea lutetiana sensu lato (Onagraceae) reconsidered. Harvard Papers in Botany 9: 255-256.

Bradshaw A.D. 1965. Evolutionary significance of phenotypic plasticity in plants. Advances in Genetics 13: 115-155.

Cain M.L., Milligan B.G. \& Strand A.E. 2000. Long-distance seed dispersal in plant populations. American Journal of Botany 87: 1217-1227.

Collard B.C.Y. \& Mackill D.J. 2009. Start Codon Targeted (SCoT) polymorphism: a simple novel DNA marker technique for generating gene-targeted markers in plants. Plant Molecular Biology Reporter 27: 86-93.

Cortés A.J., Monserrate F.A., Ramírez-Villegas J., Madrinán S. \& Blair M.W. 2013. Drought tolerance in wild plant populations: the case of common beans (Phaseolus vulgaris L.). PLoS ONE 8: e62898.

Dick C.A., Herman J.A., O’Dell R.E., Lopez-Villalobos A., Eckert C. \& Whittall J.B. 2014. Cryptic genetic subdivision in the San Benito evening primrose (Camissonia benitensis). Conservation Genetics 15: 165-175.
Duarte J.F., de Carvalho D. \& de Almeida Vieira F. 2015. Genetic conservation of Ficus bonijesulapensis RM Castro in a dry forest on limestone outcrops. Biochemical Systematics and Ecology 59: 54-62.

Eckert C., Samis K. \& Lougheed S. 2008. Genetic variation across species' geographical ranges: the central-marginal hypothesis and beyond. Molecular Ecology 17: 1170-1188.

Falush D., Stephens M. \& Pritchard J.K. 2007. Inference of population structure using multilocus genotype data: dominant markers and null alleles. Molecular Ecology Notes 7: 574-578.

Fox G.A, Kendall B.E. \& Schwinning S. 2012. Environmental heterogeneity and plants. Encyclopedia of Theoretical Ecology 258-263.

Frankham R., Briscoe D.A. \& Ballou J.D. 2002. Introduction to Conservation Genetics. Cambridge University Press, Cambridge.

Franks S.J. \& Weis A.E. 2009. Climate change alters reproductive isolation and potential gene flow in an annual plant. Evolutionary Applications 2: 481-488.

Freeland J.R., Kirk H. \& Peterson S.D. 2011. Molecular Ecology. $2^{\text {nd }}$ ed. Wiley-Blackwell, Chichester, UK.

Ghasemzadeh Baraki S., Nikzat Siahkolaee S. \& Mousavi A. 2018. Optimization of the genomic DNA extraction in some mosses. Rostaniha 19: $165-175$.

Hamasha H., Schmidt-Lebuhn A., Durka W., Schleuning M. \& Hensen I. 2013. Bioclimatic regions influence genetic structure of four Jordanian Stipa species. Plant Biology 15: 882-891.

Hammer Ø., Harper D. \& Ryan P. 2001. PAST-palaeontological statistics, ver. 1.89. Palaeontologia Electronica 4: 1-9.

Hou Y. \& Lou A. 2011. Population genetic diversity and structure of a naturally isolated plant species, Rhodiola dumulosa (Crassulaceae). PLoS ONE 6: e24497.

Hufford K.M. \& Mazer S.J. 2003. Plant ecotypes: genetic differentiation in the age of ecological restoration. Trends in Ecology \& Evolution 18: $147-155$.

Hutchison D.W. \& Templeton A.R. 1999. Correlation of pairwise genetic and geographic distance measures: inferring the relative influences of gene flow and drift on the distribution of genetic variability. Evolution 53: 1898 1914.

Kang H.W., Park D.S., Go S.J. \& Eun M.Y. 2002. Fingerprinting of diverse genomes using PCR with universal rice primers generated from repetitive sequence of Korean weedy rice. Molecules and Cells 13: 281-287

Khan M.K., Pandey A., Thomas G., Akkaya M.S., Kayis S.A., Ozsensoy Y., Hamurcu M., Gezgin S., Topal A. \& Hakki E.E. 2015. Genetic diversity and population structure of wheat in India and Turkey. AoB Plants 7: plv083.

Little C.J., Wheeler J.A., Sedlacek J., Cortés A.J. \& Rixen C. 2016. Smallscale drivers: the importance of nutrient availability and snowmelt timing on performance of the alpine shrub Salix herbacea. Oecologia 180: 1015-1024.

Losos J.B. \& Glor R.E. 2003. Phylogenetic comparative methods and the geography of speciation. Trends in Ecology and Evolution 18: 220-227.

Medrano M. \& Herrera C.M. 2008. Geographical structuring of genetic diversity across the whole distribution range of Narcissus longispathus, a habitat-specialist, Mediterranean narrow endemic. Annals of Botany 102: 183-194.

Mitton J., Latta R. \& Rehfeldt G. 1997. The pattern of inbreeding in Washoe pine and survival of inbred progeny under optimal environmental conditions. Silvae Genetica 46: 215-218. 
Nevo E. 2001. Evolution of genome-phenome diversity under environmental stress. Proceedings of the National Academy of Sciences 98: 6233-6240.

Peakall R. \& Smouse P.E. 2006. GENALEX 6: genetic analysis in Excel. Population genetic software for teaching and research. Molecular Ecology Notes 6: 288-295.

Perrier X. \& Jacquemoud-Collet J.P. 2006. DARwin software. Website: https://darwin.cirad.fr/ (Accessed Mar 15, 2011)

Podani J. 2000. Introduction to the exploration of multivariate biological data. Backhuys Publishers, Leiden.

Pole M. 2010. Cuticle morphology of Australasian Sapindaceae. Botanical Journal of the Linnean Society 164: 264-292.

Pritchard J.K., Stephens M., Donnelly P. 2000. Inference of population structure using multilocus genotype data. Genetics 155: 945-959.

Robertson A.W., Ladley J.J., Kelly D., McNutt K.L., Peterson P.G., Merrett M.F. \& Karl B.J. 2008. Assessing pollination and fruit dispersal in Fuchsia excorticata (Onagraceae). New Zealand Journal of Botany 46: 299-314

Schmitt J., Dudley S.A. \& Pigliucci M. 1999. Manipulative approaches to testing adaptive plasticity: phytochrome-mediated shade-avoidance responses in plants. American Naturalist 154: S43-S54.

Slatkin M. 1985. Gene flow in natural populations. Annual Review of Ecology and Systematics 16: 393-430.

Slatkin M. 1993. Isolation by distance in equilibrium and non-equilibrium populations. Evolution 47: 264-279.

Spehn E.M. \& Körner C. 2005. A global assessment of mountain biodiversity and its function. In Huber U.M., Bugmann H.K.M. \& Reasoner M.A. (eds.), Global Change and Mountain Regions: 393-400. Springer, Dordrecht.

Stearns S.C. 1989. Trade-offs in Life-history evolution. Functional Ecology 3: 259-268.
Still D., Kim D.H. \& Aoyama N. 2005. Genetic variation in Echinacea angustifolia along a climatic gradient. Annals of Botany 96: 467-477.

Struik G.J. 1965. Growth patterns of some native annual and perennial herbs in Southern Wisconsin. Ecology 46: 401-420.

van der Meijden R. 1990. Heukels 'flora van Nederland. $21^{\text {ste }}$ druk. WoltersNoordhoff, Groningen.

Verburg R.W., Kwant R. \& Werger M.J.A. 1996. The effect of plant size on vegetative reproduction in a pseudo-annual. Vegetatio 125 : 185-192.

Verburg R., Maas J. \& During H.J. 1998. Vegetative propagation and sexual reproduction in the woodland understorey pseudo-annual Circaea lutetiana L. Plant Ecology 134:211-224

Verburg R., Maas J. \& During H.J. 2000. Clonal diversity in differentlyaged populations of the pseudo-annual clonal plant Circaea lutetiana $\mathrm{L}$. Plant Biology 2: 646-652.

Wagner. W.L., Hoch P.C. \& Peter H. 2007. Revised classification of the Onagraceae. Systematic Botany Monographs 83: 1-240.

Wagner W.L. \& Hoch P.C. 2009. Nomenclatural Corrections in Onagraceae Novon: A Journal for Botanical Nomenclature 19: 130-132.

Weising K., Nybom H., Pfenninger M., Wolff K. \& Kahl G. 2005. DNA Fingerprinting in Plants: Principles, Methods, and Applications. CRC Press, Boca Raton.

Wheeler J.A., Schnider F., Sedlacek J., Cortés A.J., Wipf S., Hoch G. \& Rixen C. 2015. With a little help from my friends: community facilitation increases performance in the dwarf shrub Salix herbacea. Basic and Applied Ecology 16: 202-209.

Whitlock M.C. \& McCauley D.E. 1999. Indirect measures of gene flow and migration: $\mathrm{FST} \neq 1 /(4 \mathrm{Nm}+1)$. Heredity $82: 117-125$. 